\title{
DETERMINING SIZE FRACTIONS OF AN AEROSOL IN VIEW OF NEW DEFINITIONS IN POLISH REGULATION
}

\author{
PRZEMYSLAW OBERBEK \& BEATA KACZOROWSKA \\ Central Institute for Labour Protection - National Research Institute, Warsaw, Poland.
}

\begin{abstract}
A Polish regulation of the Minister of Labour and Social Policy on the value of the maximum concentrations of harmful chemical and dust factors in the workplace introduced new definitions of aerosols, which is "inhalable fraction and respirable fraction in place of the total dust and respirable dust". Due to the modification of the definitions of aerosol fractions, it is necessary to verify methods for determining the inhalable and respirable fraction of the aerosol. The purpose of the studies leading to the determination of the inhalable fraction and the respirable fraction of the aerosol is to obtain validated and reliable exposure information to compare the exposure to the limit value. The most reliable results of occupational exposure assessment are obtained using an individual dosimetry method. The research was carried out at seven selected workstations where there was emitted, for example, wood dust or coal dust. Dust samples were collected in a breathing zone on a specially constructed stand containing a set of sampling heads along with individual aspirators. At each of the investigated workstations, samples of the inhalable fraction and respirable fraction of the dust were collected simultaneously using different sets of sampling heads capable of sampling with varying volume air flow. These studies were conducted to compare the various samplers currently available on the Polish market. IOM was used as a reference personal sampler. By analyzing the results, it was found that the IOM sampler at each workstation obtained similar values (at least four IOM heads were used in one test). The biggest discrepancies can be seen with the GSP 3.5 sampler.

Keywords: aerosols, chemical hazards, coal dust, dust hazards, individual dosimetry method, inhalable fraction, occupational exposure assessment, respirable fraction, wood dust
\end{abstract}

\section{INTRODUCTION}

According to the Central Statistical Office (pol. Gtówny Urzqd Statystyczny, GUS) data on persons employed in hazardous conditions, among the work-related factors, in 2015 there were 59.8 thousand persons exposed to industrial dust [1] (Zgierska et al., 2016). The term 'industrial dust' is defined as any aerosol the dispersed phase of which is composed of solid particles (grains) within the diameter range of 0.1 to $100 \mu \mathrm{m}$, generated by activities employed in manufacturing processes. For the purpose of dust particle size determination, the following terms are employed:

- equivalent grain diameter, the diameter of a spherical particle with density identical to the density of investigated dust particle, which exhibits equal falling speed in non-turbulent air as the investigated dust particle,

- aerodynamic diameter - the diameter of a sphere with the density of $1 \mathrm{~g} / \mathrm{cm}^{3}$ which exhibits equal falling speed in non-turbulent air as the investigated dust particle,

- projection diameter - the diameter of a circle, the area of which is equivalent to the area of the investigated particle projection on the observation plane.

Particulate pollutant emissions are a consequence of most industrial processes. Among processes contributing the most to particulate pollutant emissions are: grinding, milling, sieving, transport, mixing and extraction of resources. The most harmful high-dispersion dusts are created in large concentrations during the processes of sharpening, grinding and polishing. 
Health effects of dust exposure usually become apparent after a latent period in the form of a variety of respiratory diseases, including pathological connective tissue growth (contributing to pneumoconiosis) and cancer [2] (Więcek E., 2011).

In the Ordinance of the Minister of Labour and Social Policy of 6 June 2014 on highest permissible levels of concentration and intensity of agents harmful to health in the working environment Polish (Journal of Laws 2014, item 817), considering the recommendations of the PN-EN 481:1998 [3] standard, modified definitions of aerosol fractions were introduced - notably the inhalable and the respirable fractions. Such actions are in accordance with the European approach to the determination of aerosol fractions in the working environment, shown in the EN 481:1993 [4] standard, where air sampling principles were introduced, basing on the premise that particles which can pass to the human body are in the breathing zone (around the worker's nose and mouth). In the EN:481:1993 standard, agreed on characteristics of particle size distribution by fractions are shown, approximately describing the inhalable fraction and subfractions which can enter the body through the larynx or up to nonciliated parts of the respiratory tract. The EN 481:1993 standard was introduced in Poland as the PN-EN:481:1998 standard. Particulate fraction capable of entering the human body through inhalation exposure is called inhalable fraction in the PN-EN:481:1998 standard, and the particulate fraction deposited in the gas exchange (respiratory) zone - the respirable fraction. The degree of dust penetration and deposition is dependent on particulate grain size. The inhalable fraction is composed of grains under the diameter of $100 \mu \mathrm{m}$. In the upper respiratory tract (nose, oral cavity, throat and larynx), large particles (over $30 \mu \mathrm{m}$ in diameter) are retained and subsequently excreted with mucus. Particles with grain sizes under $7 \mu \mathrm{m}$ can penetrate the gas exchange (respiratory) zone of the lung (the alveoli). The dust fraction capable of reaching the nonciliated parts of the respiratory tract is called the respirable fraction (see Fig. 1). It takes a long time to remove dust from the alveoli (approximately $50 \%$ a month). Mean aerodynamic diameter of a respirable fraction particle is $3.5 \mu \mathrm{m}$.

According to the authors [5] (Szewczyńska M., Pośniak M., 2017), it is necessary to replace probes used so far to determine total dust with probes ensuring quantitative separation of wood dusts respirable fraction in accordance with this fraction convention defined in the PN-EN 481:1998 standard. In the aforementioned article, results of studies conducted on workstations in seven furniture industry establishments were presented. Total dust and respirable fraction were determined using the gravimetric method in accordance with PN-Z-04030-05:1991 [6]

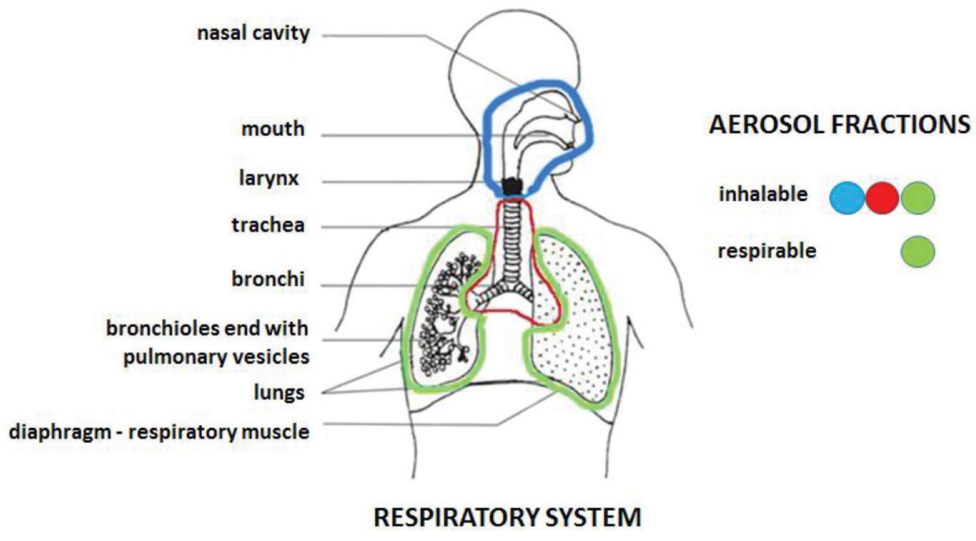

Figure 1: Respiratory system with aerosol fractions. 
and PN-Z-04030-06:1991 [7] standards. Air samples for study purposes were collected using the individual dosimetry method. Total dust concentrations were established at $0.84-13.92 \mathrm{mg} /$ $\mathrm{m}^{3}$ and inhalable fraction concentrations, obtained from total dust concentrations (after applying a 1.59 coefficient) were $1.34-22.13 \mathrm{mg} / \mathrm{m}^{3}$. Respirable fraction concentrations were $0.38-4.04 \mathrm{mg} / \mathrm{m}^{3}$, which amounts to approx. $25 \%$ of inhalable fraction on average. The results of mixed wood dusts concentration measurements in furniture manufacturing establishments indicate a significant respirable fraction percentage in the inhalable fraction of such dusts.

Methods described in the withdrawn PN-91/Z-04030/05 and PN-91/Z-04030/06 standards are currently applied in Poland. These standards describe outdated methods for dust fractions determination, therefore it its necessary to establish new standards encompassing methods of inhalable and respirable fractions in compliance with the PN-EN 481:1998 standard recommendations. The main purpose of the study was the evaluation of chosen methods as tools for determination of the inhalable and respirable factions in dusts present in working conditions. In the future, they will serve the preparation of documentations for the draft projects of two Polish standards concerning the determination of the inhalable and respirable dust fractions.

\section{METHODS AND INSTRUMENTS}

2.1 Methodology for determining the inhalable and respirable fraction of industrial dusts

The most reliable results of occupational exposure assessment are obtained using an individual dosimetry method. The research was carried out at seven selected workstations where mostly wood dust or coal dust were emitted. The methodology of this research was based on studies described by $[8,9]$. Due to fact, that side-by-side testing method was considered as the most practical, an approach based on this method was adopted in present study. Dust samples were collected in a breathing zone on a specially constructed stand containing a set of 8 or 14 sampling heads (4 pair of samplers for inhalable fraction, 3 pair of samplers for respirable fraction measurement) along with individual aspirators (see Fig. 2). At each of the

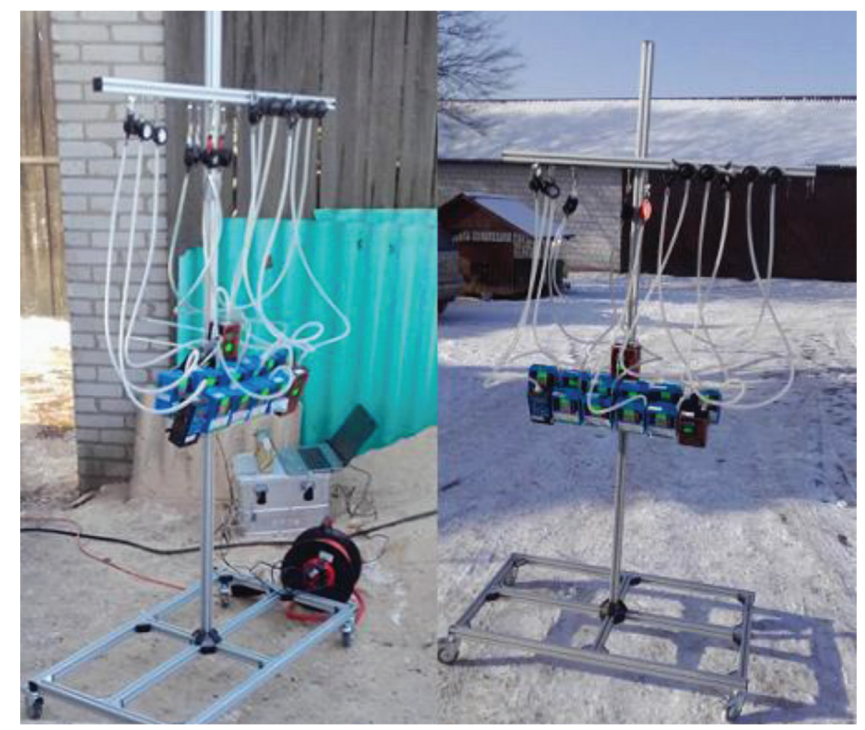

Figure 2: Arrangement of measuring sets on a stand. 
investigated workstations, samples of the inhalable fraction and respirable fraction of the dust were collected simultaneously using different sets of sampling heads capable of sampling with varying volume air flow. For each studied sampling head an IOM sampler was used as a reference. The diagram of the IOM sampling head construction is shown in Fig. 3. This sampler was developed by J.H. Vincent and D. Mark in the IOM - Institute of Occupational Medicine [10-13]. Results of dust collection were referenced to an IOM sampler which value was set as $100 \%$ and then deviations were determined.

The gravimetric method was applied in order to determine inhalable and respirable dust fractions. Inhalable fraction determination procedure was carried out through dusty air suction with a known flowrate within a specified time through a measuring filter. Dust concentration was then established as a ratio of dust mass deposited on the measuring filter to the volume of suctioned air (see eqn. 1). The respirable fraction determination was carried out through dusty air suction with a known flowrate within a specified time through a microcyclone (a preselector, designed to retain large grain diameter fractions) and subsequently a measuring filter, on which the respirable dust fraction was deposited. Respirable fraction concentration was determined as a ratio of dust mass deposited on the measuring filter to the total volume of filtered air (see eqn. 1).

$$
C=\frac{m_{2}-m_{1}}{V} \times 1000
$$

where:

- $\mathrm{m}_{2}$ - filter mass after sampling in milligrams,

- $\mathrm{m}_{1}$ - filter mass before sampling in milligrams,

- $V$-air sample volume, calculated as a product of air flowrate and sampling time in $\mathrm{dm}^{3}$.

As it is extremely important to keep the flowrate constant during air sampling, the air flowrates were checked before and after the process with a portable bubble flowmeter Gilian Gilibrator-2 (Sensidyne). During the study, environmental conditions which can potentially strongly influence dust concentrations, such as air temperature and relative humidity, were

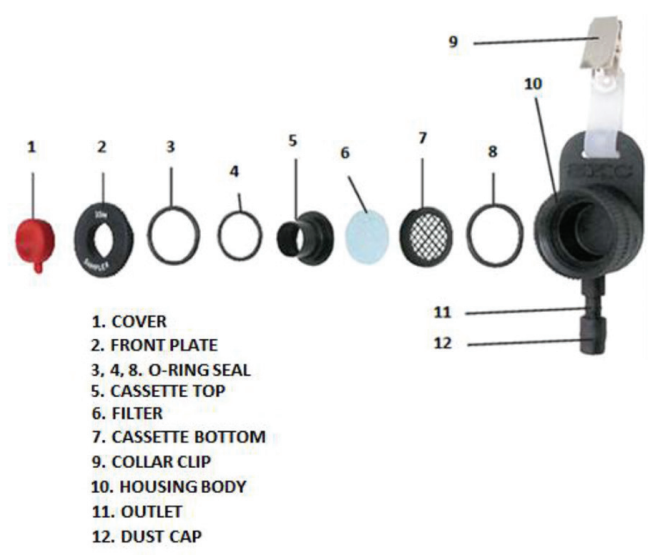

Figure 3: Diagram of the IOM sampling head construction. 
closely monitored. Before the testing commenced, on each workstation data necessary for proper results interpretation were gathered, such as:

- the kind and nature of the work process in question, as well as the kind of dust-emitting materials used,

- work timing of particular employees and the total number of employees,

- applied individual and group protection measures.

A comparative analysis of test results for different probes used for inhalable and respirable dust fraction determination was carried out in the conditions of varying flow rates, depending on the work stations where dusts of different concentrations were emitted.

The PN-91-0430/05 standard allows for sampling of inhalable dust (inhalable fraction) through the use of a stationary or a personal dust meter. Regardless of the chosen sampling method, the mass of deposited dust should be no less than $0.5 \mathrm{mg}$ and the total mass of dust collected on the filter no higher than $0.5 \mathrm{mg} / \mathrm{cm}^{2}$.

The measurements of respirable dust (respirable fraction) can be carried out through the use of a personal or a stationary dust meter as per the PN-91 Z-04030/06 standard. Sample mass deposited on a filter should not exceed $5 \mathrm{mg}$. Sample collection time must allow for the deposition of at least a minimum allowed dust mass on the filter:

- $0.3 \mathrm{mg}$, if a scale with a $0.01 \mathrm{mg}$ reading interval is used,

- $1 \mathrm{mg}$, if a scale with a $0.05 \mathrm{mg}$ reading interval is used.

Inhalable fraction and respirable fraction exposure indicators $\left(C_{w}\right)$ at the workstation were calculated as weighted averages for a working shift, in milligrams per cubic meter, using the following formula (2):

$$
C_{w}=\frac{C_{1} \times t_{1}+C_{2} \times t_{2}+\ldots+C_{n} \times t_{n}}{t_{1}+t_{2}+\ldots+t_{n}}
$$

where:

- $C_{1}, C_{2}, \ldots C_{n}-$ concentrations obtained through sample determination, in milligrams per cubic meter,

- $t_{1}, t_{2}, \ldots t_{n}$ - time of sampling for a particular sample, in hours,

- $n$ - number of samples.

The study was conducted at seven different workstations: 1 . Sawmill I (hard wood dust - Oak), 2. Joinery I (hard wood dust: Oak, Ash, Beech), 3. Joinery II (wood dust: MDF - mixture of hard wood), 4. Sawmill II (dust of soft fresh coniferous wood), 5. Joinery III (wood dust: MDF - mixture of soft wood), Coal-Fired Power Plant (coal dust and biomass), Car Workshop (dust: mixture of calcium sulphate / gypsum with magnesium). As wood dust was sampled at five of the workstations, respirable fraction tests were not carried out due to the wood dust particles being too large (and due to lack of maximum admissible concentration for wood dust).

\subsection{Measuring equipment}

The selection of studied samplers for assessment and reference sampler was dictated by the equipment available on the Polish market and the results of the works and recommendations 
described in [8-12, 14-18]. The following heads were used to determine the inhalable fraction: TWO-MET (open head), open head sampler EKOHIGIENA with an internal filter cassette (identical flow rate and construction highly like the TWO-MET probe), GSP 3.5 and GSP 10. The following heads were used to determine the respirable fraction: TWO-MET (cyclone separator), Higins-Dewell (with an upper inlet) and FSP 10. For each of the heads a reference IOM head was used, with an appropriately selected foam in case of the respirable fraction tests. Sampling heads are presented in Table 1.

The following equipment was used for sampling:

- personal aspirators, ensuring a steady airflow with a deviation no higher than $7 \%$ and flow rate ensuring proper operation of the measuring heads: Gilian-5000 (Sensidyne), Gi1Air-5 (Sensidyne), SG10-2 (GSA Messgerätebau GmbH),

Table 1: Sampling heads used for measurements.

\begin{tabular}{|c|c|c|c|c|c|}
\hline 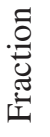 & $\begin{array}{l}\text { Name of the sampling } \\
\text { head }\end{array}$ & Image & $\begin{array}{l}\text { Air volume } \\
\text { flow } \\
{\left[\mathrm{dm}^{3} / \mathrm{min}\right]}\end{array}$ & $\begin{array}{l}\text { Filter for inhalable / } \\
\text { respirable fractions }\end{array}$ & $\begin{array}{l}\text { Size of } \\
\text { filter } \\
{[\mathrm{mm}]}\end{array}$ \\
\hline \multirow{8}{*}{ 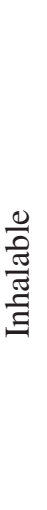 } & $1-\mathrm{IOM}$ & & 2.0 & Glass / Polypropylene & 25 \\
\hline & $\begin{array}{l}2 \text { - TWO-MET with open } \\
\text { head }\end{array}$ & & 2.0 & Glass / Polypropylene & 37 \\
\hline & $3-\mathrm{IOM}$ & & 2.0 & Glass / Polypropylene & 25 \\
\hline & $\begin{array}{l}4 \text { - EKOHIGIENA with } \\
\text { open head }\end{array}$ & & 2.0 & Glass / Polypropylene & 37 \\
\hline & $5-\mathrm{IOM}$ & & 2.0 & Glass / Polypropylene & 25 \\
\hline & $6-$ GSP 3.5 & & 3.5 & Glass / Polypropylene & 37 \\
\hline & $7-\mathrm{IOM}$ & & 2.0 & Glass / Polypropylene & 25 \\
\hline & 8 - GSP 10 & & 10.0 & Glass / Polypropylene & 37 \\
\hline \multirow{6}{*}{ 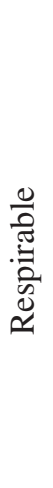 } & $\begin{array}{l}9-\mathrm{IOM} \text { with foam for } \\
\text { respiratory fraction }\end{array}$ & & 2.0 & - / Polypropylene & 25 \\
\hline & $\begin{array}{l}10 \text { - TWO-MET cyclone } \\
\text { separator }\end{array}$ & & 1.9 & - / Polypropylene & 37 \\
\hline & $\begin{array}{l}11-\text { IOM with foam for } \\
\text { respiratory fraction }\end{array}$ & & 2.0 & - / Polypropylene & 25 \\
\hline & $\begin{array}{l}12 \text { - Higgins Dewell with } \\
\text { the upper inlet }\end{array}$ & & 2.2 & - / Polypropylene & 37 \\
\hline & $\begin{array}{l}13-\mathrm{IOM} \text { with foam for } \\
\text { respiratory fraction }\end{array}$ & & 2.0 & - / Polypropylene & 25 \\
\hline & $14-$ FSP 10 & 4 & 10.0 & - / Polypropylene & 37 \\
\hline
\end{tabular}


- measuring heads: IOM - reference head (flow rate $2.0 \mathrm{dm}^{3} / \mathrm{min}$ ), TWO-MET - head with one slot for a filter cassette (dedicated for welding fumes, flow rate $2,0 \mathrm{dm}^{3} / \mathrm{min}$ ), EKOHIGIENA - open $37 \mathrm{~mm}$ diameter head with inner filter cassette (flow rate $2.0 \mathrm{dm}^{3} / \mathrm{min}$ ), GSP 3.5 (flow rate $3.5 \mathrm{dm}^{3} / \mathrm{min}$ ), GSP 10 (flow rate $10.0 \mathrm{dm}^{3} / \mathrm{min}$ ), to mount the frame where an employee breathing zone filter is placed.

- cyclone selectors for the purpose of respirable and inhalable fraction separation: IOM - reference head (flow rate $2.0 \mathrm{dm}^{3} / \mathrm{min}$ ), Higgins-Dewell (flow rate $2.2 \mathrm{dm}^{3} / \mathrm{min}$ ), TWOMET head with a cyclone separator (flow rate $1.9 \mathrm{dm}^{3} / \mathrm{min}$ ), FSP 10 (flow rate $10.0 \mathrm{dm}^{3} /$ $\mathrm{min})$. The cyclone selector is a vital part of the measuring system. Its flow rate must be adjusted in such a way to ensure respirable fraction intake. Otherwise, an intermediate phase will be deposited on the filter. The measurements will then apply to an entirely different fraction and the conclusions will be in error.

- measuring filters (non-hygroscopic filters with a filtration efficiency over 95\%): polypropylene, glass, cellulose,

- analytical scale XPE with an interval no less than $0.01 \mathrm{mg}$ (Mettler Toledo),

- desiccator for filter and humidity sensitive sample storage (WSL Sp. z o.o.),

- thermo-hygro-barometer LB-706 (with a LB-701 probe, LAB-EL),

- bubble flow meter Gilibrator-2 (Sensidyne).

\section{RESULTS AND DISCUSSION}

These studies were conducted to compare the various chosen samplers currently available on the Polish market. Results were taken from seven workstations: 1 - Sawmill I (hard wood dust - Oak), 2 - Joinery I (hard wood dust: Oak, Ash, Beech), 3 - Joinery II (wood dust: MDF mixture of hard wood), 4 - Sawmill II (dust of soft fresh coniferous wood), 5 - Joinery III (wood dust: MDF - mixture of soft wood), 6 - Coal-Fired Power Plant (coal dust and biomass), 7 - Car Workshop (dust: mixture of calcium sulphate / gypsum with magnesium).

\subsection{Pumps performance and environmental conditions}

To keep the flowrate constant during air sampling, the air flowrates were checked before and after the process. Average volume flow of the pumps were measured from values checked before and after the process. Environmental conditions, which can potentially strongly influence dust concentrations, were checked each hour of the measurements and average value was calculated (see Table 2).

All flows rates were maintained at a good level for dust sampling. Exception was the flow recorded by the pump connected to EKOHIGIENA sampler at the second workstations where the flow rate was $8.57 \%$ (should not exceed 5\%). However, the amount of dust collected by this sampler did not differ significantly from the reference value.

\subsection{Mass concentrations of collected dust}

Mass concentrations of dust collected at seven different workstations are presented in Table 3. By analysing the results, it was found that the IOM sampler at each workstation obtained similar values and were good choice as a point of reference to the other sampling heads. Small discrepancies between IOM samplers were probably caused by the distance between the measuring pairs arranged on a stand. In three cases, no dust or only trace amounts of dust were collected on the filters (results rejected). As checks of the pumps have shown, the air 
Table 2: Average volume flow for the pumps and environmental conditions during measurements.

\begin{tabular}{|c|c|c|c|c|c|c|c|}
\hline \multirow{3}{*}{$\begin{array}{l}\text { Type of head connected to } \\
\text { a specific pump }\end{array}$} & \multicolumn{7}{|c|}{ Average volume flow $\left[\mathrm{dm}^{3} / \mathrm{min}\right]$ ( $\%$ change of indication) } \\
\hline & \multicolumn{7}{|c|}{ Workstation } \\
\hline & 1 & 2 & 3 & 4 & 5 & 6 & 7 \\
\hline 1 - IOM ref. & $\begin{array}{l}2.009 \\
(1.64 \%)\end{array}$ & $\begin{array}{l}2.003 \\
(0.31 \%)\end{array}$ & $\begin{array}{l}2.015 \\
(0.39 \%)\end{array}$ & $\begin{array}{l}1.995 \\
(0.21 \%)\end{array}$ & $\begin{array}{l}1.997 \\
(0.74 \%)\end{array}$ & $\begin{array}{l}2.000 \\
(0.16 \%)\end{array}$ & $\begin{array}{l}2.026 \\
(2.63 \%)\end{array}$ \\
\hline $\begin{array}{l}2 \text { - TWO-MET with open } \\
\text { head }\end{array}$ & $\begin{array}{l}2.043 \\
(4.57 \%)\end{array}$ & $\begin{array}{l}2.034 \\
(3.49 \%)\end{array}$ & $\begin{array}{l}2.010 \\
(0.38 \%)\end{array}$ & $\begin{array}{l}1.998 \\
(1.14 \%)\end{array}$ & $\begin{array}{l}2.000 \\
(0.38 \%)\end{array}$ & $\begin{array}{l}2.012 \\
(1.40 \%)\end{array}$ & $\begin{array}{l}2.001 \\
(0.09 \%)\end{array}$ \\
\hline 3 - IOM ref. & $\begin{array}{l}2.017 \\
(1.71 \%)\end{array}$ & $\begin{array}{l}1.996 \\
(1.11 \%)\end{array}$ & $\begin{array}{l}1.993 \\
(0.20 \%)\end{array}$ & $\begin{array}{l}2.019 \\
(0.51 \%)\end{array}$ & $\begin{array}{l}2.003 \\
(0.26 \%)\end{array}$ & $\begin{array}{l}1.975 \\
(2.09 \%)\end{array}$ & $\begin{array}{l}2.021 \\
(2.74 \%)\end{array}$ \\
\hline $\begin{array}{l}4 \text { - EKOHIGIENA, open } \\
\text { head with inner cassette }\end{array}$ & $\begin{array}{l}2.008 \\
(0.85 \%)\end{array}$ & $\begin{array}{l}2.089 \\
(\mathbf{8 . 5 7 \% )}\end{array}$ & $\begin{array}{l}2.003 \\
(0.60 \%)\end{array}$ & $\begin{array}{l}1.997 \\
(1.32 \%)\end{array}$ & $\begin{array}{l}2.006 \\
(0.54 \%)\end{array}$ & $\begin{array}{l}1.995 \\
(0.18 \%)\end{array}$ & $\begin{array}{l}2.002 \\
(0.37 \%)\end{array}$ \\
\hline 5- IOM ref. & $\begin{array}{l}2.022 \\
(2.27 \%)\end{array}$ & $\begin{array}{l}2.010 \\
(0.84 \%)\end{array}$ & $\begin{array}{l}2.032 \\
(2.33 \%)\end{array}$ & $\begin{array}{l}2.012 \\
(1.62 \%)\end{array}$ & $\begin{array}{l}2.021 \\
(2.63 \%)\end{array}$ & $\begin{array}{l}2.008 \\
(0.51 \%)\end{array}$ & $\begin{array}{l}1.999 \\
(0.24 \%)\end{array}$ \\
\hline $6-$ GSP 3.5 & $\begin{array}{l}3.536 \\
(2.01 \%)\end{array}$ & $\begin{array}{l}3.532 \\
(1.16 \%)\end{array}$ & $\begin{array}{l}3.540 \\
(0.47 \%)\end{array}$ & $\begin{array}{l}3.506 \\
(0.10 \%)\end{array}$ & $\begin{array}{l}3.499 \\
(0.41 \%)\end{array}$ & $\begin{array}{l}3.493 \\
(0.09 \%)\end{array}$ & $\begin{array}{l}3.525 \\
(1.24 \%)\end{array}$ \\
\hline 7 - IOM ref. & $\begin{array}{l}2.040 \\
(3.81 \%)\end{array}$ & $\begin{array}{l}1.994 \\
(\% 1.05)\end{array}$ & $\begin{array}{l}1.976 \\
(1.62 \%)\end{array}$ & $\begin{array}{l}1.995 \\
(1.44 \%)\end{array}$ & $\begin{array}{l}1.987 \\
(1.34 \%)\end{array}$ & $\begin{array}{l}2.003 \\
(0.38 \%)\end{array}$ & $\begin{array}{l}1.993 \\
(0.83 \%)\end{array}$ \\
\hline 8 - GSP 10 & $\begin{array}{l}10.247 \\
(4.29 \%)\end{array}$ & $\begin{array}{l}10.012 \\
(0.25 \%)\end{array}$ & $\begin{array}{l}10.146 \\
(2.51 \%)\end{array}$ & $\begin{array}{l}10.003 \\
(0.45 \%)\end{array}$ & $\begin{array}{l}10.038 \\
(0.91 \%)\end{array}$ & $\begin{array}{l}10.072 \\
(1.84 \%)\end{array}$ & $\begin{array}{l}10.163 \\
(2.11 \%)\end{array}$ \\
\hline 9 - IOM ref. & - & - & - & - & - & $\begin{array}{l}2.005 \\
(0.88 \%)\end{array}$ & $\begin{array}{l}2.005 \\
(0.40 \%)\end{array}$ \\
\hline $\begin{array}{l}10 \text { - TWO-MET with } \\
\text { cyclone separator }\end{array}$ & - & - & - & - & - & $\begin{array}{l}1.898 \\
(0.26 \%)\end{array}$ & $\begin{array}{l}1.909 \\
(0.28 \%)\end{array}$ \\
\hline $\begin{array}{l}11-\mathrm{IOM} \text { with foam for } \\
\text { respiratory fraction }\end{array}$ & - & - & - & - & - & $\begin{array}{l}1.994 \\
(0.37 \%)\end{array}$ & $\begin{array}{l}2.000 \\
(0.33 \%)\end{array}$ \\
\hline $\begin{array}{l}12 \text { - Higgins Dewell with } \\
\text { the upper inlet }\end{array}$ & - & - & - & - & - & $\begin{array}{l}2.194 \\
(0.63 \%)\end{array}$ & $\begin{array}{l}2.197 \\
(0.10 \%)\end{array}$ \\
\hline $\begin{array}{l}13 \text { - IOM with foam for } \\
\text { respiratory fraction }\end{array}$ & - & - & - & - & - & $\begin{array}{l}1.994 \\
(0.11 \%)\end{array}$ & $\begin{array}{l}2.006 \\
(1.01 \%)\end{array}$ \\
\hline \multirow[t]{2}{*}{$14-$ FSP 10} & - & - & - & - & - & $\begin{array}{l}10.371 \\
(0.83 \%)\end{array}$ & $\begin{array}{l}10.256 \\
(3.13 \%)\end{array}$ \\
\hline & 1 & 2 & 3 & 4 & 5 & 6 & 7 \\
\hline Air temperature $\left[{ }^{\circ} \mathrm{C}\right]$ & $\begin{array}{l}-1.60 \div \\
1.90\end{array}$ & $\begin{array}{l}23.7 \div \\
24.0\end{array}$ & $\begin{array}{l}18.4 \div \\
24.5\end{array}$ & $\begin{array}{l}16.0 \div \\
17.4\end{array}$ & $\begin{array}{l}18.3 \div \\
18.5\end{array}$ & $\begin{array}{l}25.6 \div \\
27.3\end{array}$ & $\begin{array}{l}22.7 \div \\
24.9\end{array}$ \\
\hline Relative air humidity [\%] & $\begin{array}{l}62.90 \div \\
72.10\end{array}$ & $\begin{array}{l}37.8 \div \\
38.2\end{array}$ & $\begin{array}{l}31.0 \div \\
35.7\end{array}$ & $\begin{array}{l}66.6 \div \\
71.0\end{array}$ & $\begin{array}{l}61.0 \div \\
63.0\end{array}$ & $\begin{array}{l}31.5 \div \\
42.0\end{array}$ & $\begin{array}{l}50.6 \div \\
61.5\end{array}$ \\
\hline Sampling time [min] & 303 & 316 & 263 & 242 & 223 & 170 & 366 \\
\hline
\end{tabular}


Table 3: Mass concentrations of collected dust.

\begin{tabular}{|c|c|c|c|c|c|c|c|c|}
\hline \multirow[b]{3}{*}{ Head number } & \multirow[b]{3}{*}{ Fraction } & \multicolumn{7}{|c|}{ Mass concentration of dust $\left[\mathrm{mg} / \mathrm{m}^{3}\right]$} \\
\hline & & \multicolumn{7}{|c|}{ Workstation } \\
\hline & & 1 & 2 & 3 & 4 & 5 & 6 & 7 \\
\hline 1 (ref IOM) & Inhalable & 1.16 & 0.38 & 0.49 & 0.75 & 2.35 & 4.29 & 9.47 \\
\hline 2 & & 0.97 & 0.30 & 0.40 & 0.13 & 1.48 & 4.68 & 9.95 \\
\hline 3 (ref IOM) & & 1.38 & 0.38 & 0.41 & 0.46 & 2.00 & 5.27 & 10.02 \\
\hline 4 & & 1.29 & 0.50 & 0.62 & 0.25 & 1.25 & 11.15 & 9.78 \\
\hline 5 (ref IOM) & & 1.95 & 0.34 & 0.46 & 0.54 & 1.68 & 5.31 & 9.75 \\
\hline 6 & & 1.93 & $\mathbf{0 . 0 0}$ & 0.00 & 2.33 & 3.62 & 2.90 & 11.35 \\
\hline 7 (ref IOM) & & 1.63 & 0.67 & 0.47 & 0.79 & 2.02 & 5.60 & 9.94 \\
\hline 8 & & 2.18 & 0.23 & 0.30 & 0.88 & 0.62 & 3.86 & 9.88 \\
\hline 9 (ref IOM) & Respirable & - & - & - & - & - & 0.26 & 1.25 \\
\hline 10 & & - & - & - & - & - & 0.20 & 1.93 \\
\hline 11 (ref IOM) & & - & - & - & - & - & 0.14 & 1.22 \\
\hline 12 & & - & - & - & - & - & 0.17 & 1.71 \\
\hline 13 (ref IOM) & & - & - & - & - & - & 0.56 & 0.86 \\
\hline 14 & & - & - & - & - & - & 0.00 & 2.89 \\
\hline
\end{tabular}

flow was undisturbed and they worked properly, also filters were not clogged by larger objects (like leaves, plastic pieces, paper scraps, etc.). Lack of dust on the filters could be caused by leaks, poorly placed or damaged filter. Interestingly, on the days when there was a problem with dust collection (workstation 2 and 3 ) humidity was relatively lower than the other days. At the second workstation, also the ECKOHIGIENA sampler pump had disturbed airflow. With so few results it is not a determinant, but it is worth keeping in mind for further research.

\subsection{Deviation from the reference values}

Results of dust collection were referenced to IOM samplers which value was set as $100 \%$ and then deviations were determined as percentage differences (see Fig. 4). Average percentage deviation from reference value shown that the biggest discrepancies can be seen with the GSP 3.5 sampler for inhalable fraction (over 100\%). EKOHIGIENA sampler had discrepancies around $40 \%$, GSP 10, around 35\% and TWO-MET sampler (with open head) around $27 \%$. Samplers: Higgins Dewell and TWO-MET (with cyclone separator) used for respirable fractions had discrepancies around 30-38\% and FSP 10 collected nearly 2.5 times more dust than reference IOM sampler, but this is only based on one result. Second result for this sampler was rejected because no dust or only trace amounts of dust was collected. Same problem appeared twice in case of GSP 3.5 sampler. 


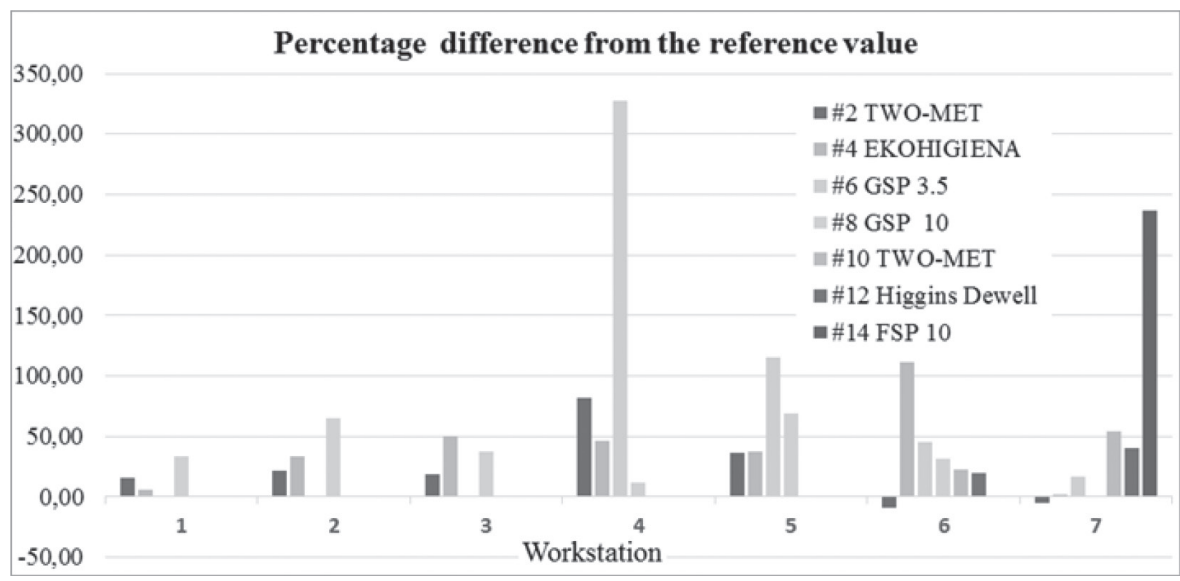

Figure 4: Percentage deviations from reference value.

\subsection{Exposure indicators}

Measurement of dust concentrations allowed to determine the level of exposure. Workplace activities and the type of dust the worker was exposed to: 1 . Woodcutter - cutting boards (hard wood; oak dust), 2. Carpenter - cutting board (hard wood; oak, ash, beech dust), 3. Carpenter - cutting MDF (medium-density fibreboard, mixture of hard wood). 4. Woodcutter - cutting of fresh coniferous wood (soft coniferous wood dust), 5. Carpenter - cutting MDF (medium-density fibreboard, mixture of soft wood), 6. Physical worker - staying in a pouring building at the level of the sifters (coal dust and biomass), 7. Grinder - grinding of the filler compound (mixture of calcium sulphate with magnesium). See Table 4.

At the workstations where wood, coal and calcium sulphate dust was emitted no threshold values for inhalable and respirable fractions were exceeded. Only at the car wokshop values for inhalable fraction was slightly exceeded.

\section{CONCLUSION}

Pilot studies have shown that a method of simultaneously collected dust at workstations with use of reference samplers gives an opportunity to determine size fractions of an aerosol, exposure indicators and to evaluate selected samplers in view of new definitions in Polish regulations. Unfortunately, we did not avoid errors during the measurements, and the method itself needs to be modified. In subsequent studies the most important will be an increase of the measurement statistics. Next studies are planned, but with repeating the dust collection at the respective worksites for at least another two days (at least 3 samples for each sampling head). As the amounts of dusts present in work environments are getting progressively smaller, currently applied mass based approaches may potentially be not precise enough for the purpose of such study. This is the reason for which dust concentration measurements in further studies will be simultaneously carried out with use of standardized testing methods and measuring instruments capable of detecting mass concentration $\left(\mathrm{mg} / \mathrm{m}^{3}\right.$ ) and particles number concentration (number of particles/ $\mathrm{cm}^{3}$ ) like portable aerosol spectrometers and ultrafine particle counters. 
Table 4: Exposure indicators for different studied activities.

\begin{tabular}{|c|c|c|c|c|c|c|c|}
\hline \multirow[b]{2}{*}{ Head number } & \multicolumn{7}{|c|}{ Workstation / activities; $C w\left[\mathrm{mg} / \mathrm{m}^{3}\right] \pm$ expanded uncertainty } \\
\hline & 1 & 2 & 3 & 4 & 5 & 6 & 7 \\
\hline \multirow[t]{2}{*}{1} & 1.17 & 0.38 & 0.50 & 0.74 & 2.35 & 4.29 & 9.59 \\
\hline & \pm 0.12 & \pm 0.04 & \pm 0.05 & \pm 0.08 & \pm 0.08 & \pm 0.44 & \pm 0.98 \\
\hline \multirow[t]{2}{*}{2} & 0.94 & 0.30 & 0.40 & 0.13 & 1.48 & 4.71 & 9.96 \\
\hline & \pm 0.10 & \pm 0.03 & \pm 0.04 & \pm 0.01 & \pm 0.01 & \pm 0.48 & \pm 1.02 \\
\hline \multirow[t]{2}{*}{3} & 1.39 & 0.38 & 0.41 & 0.46 & 2.00 & 5.20 & 10.13 \\
\hline & \pm 0.14 & \pm 0.04 & \pm 0.04 & \pm 0.05 & \pm 0.05 & \pm 0.53 & \pm 1.03 \\
\hline \multirow[t]{2}{*}{4} & 1.30 & 0.53 & 0.62 & 0.25 & 1.25 & 11.12 & 9.79 \\
\hline & \pm 0.13 & \pm 0.05 & \pm 0.06 & \pm 0.03 & \pm 0.03 & \pm 1.13 & \pm 1.00 \\
\hline \multirow[t]{2}{*}{5} & 1.97 & 0.34 & 0.47 & 0.55 & 1.70 & 5.34 & 9.74 \\
\hline & \pm 0.20 & \pm 0.04 & \pm 0.05 & \pm 0.06 & \pm 0.06 & \pm 0.54 & \pm 0.99 \\
\hline \multirow[t]{2}{*}{6} & 1.94 & 0.00 & 0.00 & 2.33 & 3.62 & 2.90 & 11.44 \\
\hline & \pm 0.20 & & & \pm 0.24 & \pm 0.24 & \pm 0.30 & \pm 1.17 \\
\hline \multirow[t]{2}{*}{7} & 1.66 & 0.67 & 0.47 & 0.78 & 2.01 & 5.61 & 9.91 \\
\hline & \pm 0.17 & \pm 0.07 & \pm 0.05 & \pm 0.08 & \pm 0.08 & \pm 0.57 & \pm 1.01 \\
\hline \multirow[t]{2}{*}{8} & 2.23 & 0.23 & 0.30 & 0.88 & 0.63 & 3.89 & 10.04 \\
\hline & \pm 0.23 & \pm 0.02 & \pm 0.03 & \pm 0.09 & \pm 0.09 & \pm 0.40 & \pm 1.02 \\
\hline \multirow[t]{2}{*}{9} & & & & & & 0.26 & 1.25 \\
\hline & & & & & & \pm 0.03 & \pm 0.13 \\
\hline \multirow[t]{2}{*}{10} & & & & & & 0.20 & 1.94 \\
\hline & & & & & & \pm 0.02 & \pm 0.20 \\
\hline \multirow[t]{2}{*}{11} & & & & & & 0.14 & 1.22 \\
\hline & & & & & & \pm 0.01 & \pm 0.12 \\
\hline \multirow[t]{2}{*}{12} & & & & & & 0.17 & 1.70 \\
\hline & & & & & & \pm 0.02 & \pm 0.17 \\
\hline \multirow[t]{2}{*}{13} & & & & & & 0.56 & 0.86 \\
\hline & & & & & & \pm 0.06 & \pm 0.09 \\
\hline \multirow[t]{2}{*}{14} & & & & & & 0.00 & 2.97 \\
\hline & & & & & & & \pm 0.3 \\
\hline \multirow[t]{2}{*}{ Average } & $1.58 /-$ & $0.40 /-$ & $0,45 /-$ & $0.77 /-$ & $1.88 /-$ & $5.38 /$ & $10.08 /$ \\
\hline & & & & & & 0.27 & 1.66 \\
\hline Threshold limit & $2 /-$ & $2 /-$ & $2 /-$ & $4 /-$ & $4 /-$ & $10 / 2$ & $10 / 2$ \\
\hline \multicolumn{8}{|l|}{ Value $\left[\mathrm{mg} / \mathrm{m}^{3}\right]$} \\
\hline Inhalable / respirable & & & & & & & \\
\hline
\end{tabular}

\section{ACKNOWLEDGEMENTS}

This paper has been based on the results of a research task carried out within the statutory activity of Central Institute for Labour Protection - National Research Institute (task number I-52/TSB). Studies were conducted to compare the various samplers currently available on the Polish market. This article does not constitute an advertisement of any of the listed companies. The publication is of a review nature. Information were obtained from companies producing and distributing heads for respiratory and respiratory fractions (websites: SKC, Zeff, Casella, Ekohigiena). 


\section{REFERENCES}

[1] Zgierska, A., Working Conditions in 2016, Central Statistical Office Report (pol. Główny Urząd Statystyczny, GUS), Warsaw 2016.

[2] Więcek, E., Health criteria for aerosol sampling in the work environment, Principles and Methods of Assessing the Working Environment, 2011.

[3] PN-EN 481:1998, Polish Standard for: Workplace atmospheres - Size fraction definitions for measurement of airborne particles, 1998.

[4] EN 481:1993, European Standard: Workplace atmospheres - Size fraction definitions for measurement of airborne particles, 1993.

[5] Szewczynska, M. \& Posniak, M., Assessment of occupational exposure to wood dust in the Polish furniture industry. Occupational Medicine, 68(1), pp. 45-60, 2017. https://doi.org/10.13075/mp.5893.00458

[6] PN-91/Z-04030/05, Polish Standard for: Air purity protection. Investigation of dust content. Determination of total dust at work stations by filter-weight method, 1991.

[7] PN-91/Z-04030/06, Polish Standard for: Air purity protection. Investigation of dust content. Determination of total dust at work stations by filter-weight method, 1991.

[8] Lidén, G, Juringe, L. \& Gudmundsson, A., Workplace validation of a laboratory evaluation test of samplers for inhalable and "total" dust. Journal of Aerosol Science, 31(2), pp. 199-219, 2000.

https://doi.org/10.1016/s0021-8502(99)00049-X

[9] Lee, T., Harper, M., Slaven, J.E., Lee, K., Rando, R.J. \& Maples, E.H., Wood dust sampling: field evaluation of personal samplers when large particles are present. Annals of Occupational Hygiene, 55(2), pp. 180-191, 2011.

https://doi.org/10.1093/annhyg/meq075

[10] General methods for sampling and gravimetric analysis of respirable and inhalable dust. HSE, MDHS14/3, 2000.

[11] Sanchez Jimenez, A., van Tongeren, M. \& Aitken, R.J., Guidance for collection of inhalable and respirable in dust, Strategic Consulting. Institute of Occupational Medicine, 538-0000, 2012.

[12] Sanchez Jimenez, A., van Tongeren, M. \& Cherrie, J.W., A review of a monitoring methods for inhalable hardwood dust, Research Report. Institute of Occupational Medicine, P937/1A, 2011.

[13] LEE, T., Kim, S.W., Chisholm, W.P., Slaven, J. \& Harper, M., Performance of high flow rate samplers for respirable particle collection. Annals of Occupational Hygiene, 54(6), pp. 697-709, 2010.

https://doi.org/10.1093/annhyg/meq050

[14] Kenny, L.C., Aitken, R., Chalmers, C., Fabries, J., Gonzalezfernandez, E., Kromhout, H., Liden, G., Mark, D., Riediger, G. \& Prodi, V., A collaborative European study of personal inhalable aerosol sampler performance. Annals of Occupational Hygiene, 41(2), pp. 135-153, 1997.

https://doi.org/10.1016/s0003-4878(96)00034-8

[15] Li, S.-N., Lundgren. D.A. \& Rovell-Rixx, D., Evaluation of six inhalable aerosol samplers. AIHAJ A Journal for the Science of Occupational and Environmental Health and Safety, 61(4), pp. 506-516, 2000. https://doi.org/10.1080/15298660008984562 
[16] Kenny, L., Chung, K., Dilworth, M., Hammond, C., Jones, J.W., Shreeve, Z. \& Winton, J., Applications of low-cost, dual-fraction dust samplers. Annals of Occupational Hygiene, 45(1), pp. 35-42, 2001.

https://doi.org/10.1016/S0003-4878(00)00008-9

[17] Görner, P., Simon, X., Wrobel, R., Kauffer, E. \& Witschger, O., Laboratory study of selected personal inhalable aerosol samplers. Annals of Occupational Hygiene, 54(2), pp. $165-187,2010$.

https://doi.org/10.1093/annhyg/mep079

[18] Verpaele, S. \& Jouret, J., A comparison of the performance of samplers for respirable dust in workplaces and laboratory analysis for respirable quartz. Annals of Occupational Hygiene, 57(1), pp. 54-62, 2013.

https://doi.org/10.1093/annhyg/mes038 